\title{
Alcohol and arrhythmias: a comprehensive review.
}

\author{
Anil George \\ Brody School of Medicine, Pitt County Memorial Hospital \\ Vincent M. Figueredo, M.D. \\ Thomas Jefferson University
}

\section{Follow this and additional works at: https://jdc.jefferson.edu/cardiologyfp \\ Part of the Cardiology Commons \\ Let us know how access to this document benefits you}

\section{Recommended Citation}

George, Anil and Figueredo, M.D., Vincent M., "Alcohol and arrhythmias: a comprehensive review." (2010). Division of Cardiology Faculty Papers. Paper 14.

https://jdc.jefferson.edu/cardiologyfp/14

This Article is brought to you for free and open access by the Jefferson Digital Commons. The Jefferson Digital Commons is a service of Thomas Jefferson University's Center for Teaching and Learning (CTL). The Commons is a showcase for Jefferson books and journals, peer-reviewed scholarly publications, unique historical collections from the University archives, and teaching tools. The Jefferson Digital Commons allows researchers and interested readers anywhere in the world to learn about and keep up to date with Jefferson scholarship. This article has been accepted for inclusion in Division of Cardiology Faculty Papers by an authorized administrator of the Jefferson Digital Commons. For more information, please contact: JeffersonDigitalCommons@jefferson.edu. 


\title{
As submitted to:
}

\section{Journal of Cardiovascular Medicine}

\author{
And later published as:
}

\section{Alcohol and Arrhythmias: A Comprehensive Review}

\author{
Volume 11, Issue 4, April 2010, Pages 221-228
}

\section{DOI: 10.2459/JCM.0b013e328334b42d}

\author{
Anil George ${ }^{a}$ and Vincent M. Figueredo ${ }^{b}$ \\ ${ }^{a}$ The Brody School of Medicine, Pitt County Memorial Hospital \\ ${ }^{\mathrm{b}}$ Einstein Institute for Heart and Vascular Health, Albert Einstein Medical Center, and \\ Jefferson Medical College, Philadelphia, PA
}

Key words: alcohol, ethanol, supraventricular tachycardia, atrial fibrillation, ventricular tachycardia, sudden cardiac death

Running title: Alcohol and Arrhythmias

Disclosures: No conflicts of interest

Corresponding author:

Vincent M. Figueredo, MD

Einstein Heart and Vascular Center

5501 Old York Road, Levy 3232

Philadelphia, PA 19141

Phone: $215-456-8991$

Fax: 215-456-3533

Email: figueredov@einstein.edu 


\begin{abstract}
The use of alcohol as a social lubricant is ubiquitous in human societies since ancient times. It has also long been recognized that alcohol produces undesirable cardiovascular effects, especially when imbibed in excess. Numerous investigators have noted a causal relationship between alcohol and arrhythmias, as well as sudden cardiac death. We have undertaken a comprehensive review of the literature on alcohol as a potential trigger for arrhythmias. We have reviewed the major epidemiological studies undertaken on this subject. We have also explored pathophysiological mechanisms that drive the arrythmogenic effects of alcohol. In conclusion although there is definite proof in the literature to implicate alcohol as a culprit in arrhythmias, the relationship is complex.
\end{abstract}




\section{Introduction}

Alcohol (French alcool/; Arabic al-kuhl) refers to the intoxicating constituent of wine, beer, spirits or any of numerous beverages consumed in almost all societies for over 7000 years. The term is used interchangeably with ethanol or ethyl alcohol $\left(\mathrm{C}_{2} \mathrm{H}_{5} \mathrm{OH}\right)$.

Recorded history has liberal references to alcohol use and some mention of the ill effects of it, especially in religious inscriptions. The earliest writings pertaining to the consumption of alcohol can be found in Mesopotamian clay tablets which date to 4000 $\mathrm{BC}(1)$. Societal and religious taboos prohibiting excess indulgence of alcohol can be found dating from the code of Hammurabi of Babylon (circa.1700 BC), ancient Egypt, imperial China, Persia and Buddhist India ( $5^{\text {th }}$ century BC) $(1) .$. Both the Old and New Testaments of the Bible and the Koran abound with references to the use of alcohol, as well as warnings against its abuse. As early as the nineteenth century, alcohol abuse was reported in the medical literature as detrimental to the heart. Examples included the Munich Beer Heart as reported by German pathologist Otto Bollinger, and the Tubingen Wine Heart, both popular references to deleterious consequences of alcohol excess identified during the early $20^{\text {th }}$ century.

The latter half of the twentieth century witnessed considerable attention on the beneficial effects of alcohol, especially when consumed in moderation. Potential beneficial effects include reductions in total and cardiovascular mortality, coronary heart disease events, ischemic cerebrovascular events, and sudden cardiac death. Increased HDL, reduced plasma viscosity, decreased fibrinogen concentration, increased 
fibrinolysis, decreased platelet aggregation and coagulation, and enhanced endothelial function are some of the mechanisms by which alcohol is thought to benefit the cardiovascular system (2). In the same vein we must mention that adverse cardiovascular effects from alcohol especially when imbibed in excess over long periods of time include alcoholic cardiomyopathy, hypertension and strokes.

Another important facet to the many effects of alcohol on the heart relates to its effects on heart rhythm and arrhythmias. In this review we will discuss the literature implicating alcohol as a culprit in the etiology of arrhythmias. We review basic science reports and animal models on this subject. We will discuss the types of arrhythmias seen, the levels of alcohol and or drinking patterns implicated, and potential pathophysiological mechanisms.

\section{Alcohol and arrhythmias}

Numerous nineteenth century physicians noted an adverse relationship between chronic intake of excessive amounts of alcohol and heart disease. William MacKenzie is credited with having coined the term "alcoholic heart disease" in his text book from 1902 titled "Study of the Pulse" (3, 4). In 1929, reports on cardiac beriberi reported a "hyperkinetic circulatory state" but no arrhythmias, although the electrocardiogram was noted to show tachycardia and a shortened conduction time $(5,6)$. In 1959, William Evans reported on characteristic $\mathrm{T}$ wave changes (dimple, cloven, spinous, and blunt) in the electrocardiograms of alcoholic patients(7). He also noted the presence of atrial 
fibrillation (AF), paroxysmal atrial tachycardia (PAT) and bundle branch blocks (7). In a study of 50 patients at London Hospital, Bridgen and Robinson reported that half of the patients had AF at some time; nodal rhythm, ventricular extra systoles, complete heart block, left and right bundle branch blocks were also noted(8).In 1978 Ettinger and colleagues, coined the term "holiday heart" defined as "an acute cardiac rhythm and or conduction disturbance associated with heavy ethanol consumption in a person without other clinical evidence of heart disease and disappearing without evident residual, with abstinence." (9). The most common arrhythmia noted in this study was AF; others were atrial flutter (AFL), junctional tachycardia, isolated premature ventricular complexes (PVC), isolated premature atrial complexes (PAC), paroxysmal atrial tachycardia (PAT) and ventricular tachycardia (VT).

\section{Clinical Features pertaining to Alcohol induced Arrhythmias}

\section{Alcohol and Supraventricular Arrhythmias}

Of all alcohol-induced supraventricular arrhythmias, the evidence is most compelling for AF. One of the earliest studies to address the relationship between alcohol and AF was a retrospective review in flying personnel by Lamb and Pollard in 1964(10).

Of the 60 case histories reviewed, there were at least six instances of AF where excessive alcohol ingestion was noted. Furthermore, it was observed that bouts of AF occurred in the early hours of the morning or upon arising from an alcoholic binge. Ettinger et al., reported a seasonal peak in the incidence of arrhythmias at the end of the year and New Year's Day; the "holiday heart". AF was the most common arrhythmia, followed by AFL 
and PVC's (9). Although this study was a retrospective review with a small sample size it succeeded in generating a lot of interest in the medical community.

Koskinen et al., queried the amount of alcohol consumed during the week preceding AF in 100 patients. They found that $15-30 \%$ of idiopathic AF may be alcohol related, and 5-10\% of new episodes of AF can be explained by alcohol ( Figure 1)(11). In another study by the same group, self reported alcohol consumption was higher in young and middle aged patients with recurrent AF (especially males) compared to matched hospital control subjects(12).

Djoussé et al., using data from 10,333 subjects in the Framingham Study found that consumption of alcohol above $36 \mathrm{~g} /$ day increased the risk of AF by $34 \%$, after adjusting for potential confounders(13). Of note, one alcoholic beverage equals $13.7 \mathrm{~g}$ of ethanol. Frost et al., reported in a prospective cohort study of 47,949 Danes, the Danish Diet, Cancer and Health Study, an increasing risk of AF and AFL in men, but not in women, with an average intake of alcohol of $20 \mathrm{~g} /$ day or more(14). In the prospective cohort study of 16,415 Danes, the Copenhagen City Heart Study, Mukamel et al., found that alcohol intake of 35 or more drinks per week was associated with higher AF risk in men(15). In the Women's Health Study, Conen et al., found that in healthy middle-aged women, alcohol consumption of up to 2 drinks per day was not associated with increased risk of AF (16).. However, in the subset of women consuming 2 or more drinks, the risk of AF was 1.6 times higher than women who did not consume alcohol. 
Marcus et al., studied the association between AF/AFL and alcohol intake in 195 consecutive patients, specifically measuring the right Atrial Effective Refractory Period (AERP)(17). This study is also important because the authors found that daily alcohol intake was associated with a shorter right AERP $(\mathrm{p}=0.025)$ and increased AFL in patients less than sixty years of age. The authors hypothesize that the shorter right AERP allows the right atrium to sustain a rapid rate in response to an initiating rhythm or to allow propagation of a critically timed PAC, thus suggesting a causal relationship for arrhythmias.

The evidence that alcohol predisposes to other types of supraventricular arrhythmias such as PAT is less impressive than with AF. A Kaiser Permanente study by Cohen et al., found an association between heavier drinking ( $6+$ drinks vs. $<1$ drink) and all types of supraventricular arrhythmias(18). Koskinen and Kupari noted that coexistent electrolyte abnormalities and infections (or other acute illnesses) may act together with alcohol to produce supraventricular arrhythmias(19). Table I summarizes epidemiological studies pertaining to alcohol and its role in supraventricular arrhythmias.

Thus, data suggest a dose response relationship between alcohol and supraventricular arrhythmias. Larger studies such as the Kaiser Permanente Study, the Framingham Study, Danish Diet, Cancer and Health Study, the Copenhagen City Heart Study and the Women's Health Study involved over 10,000 subjects each and controlled 
for confounders. However the sheer diversity in the design and scope of these studies makes further conclusions difficult.

\section{Protective Effect of Alcohol against Supraventricular Arrhythmias}

While the above studies support the commonly observed association between alcohol and supraventricular arrhythmias, a few studies have noted a protective effect of alcohol against AF. Notably, Psaty et al., studied the incidence of AF among older adults during 3 years of follow-up in the Cardiovascular Health Study. Alcohol use was inversely associated with AF incidence(20). The low level of alcohol use (2-3 drinks/week), as well as the low incidence of binge drinking in this older cohort, may explain this finding. It thus appears that the relationship between alcohol and arrhythmias may be non-linear involving complex interactions among variables such as dose, drinking pattern, age and sex.

\section{Alcohol and Ventricular Arrhythmias and Sudden Cardiac Death}

The relationship between alcohol and VT as well as sudden cardiac death (SCD) is definite, albeit not straightforward. VT and SCD are discussed together here as the pathophysiological operators underlying both conditions are likely common. Epidemiological data from numerous studies suggests the risk of VT/SCD to be lower in individuals with low alcohol intake (2-6 drinks/week) compared to those who rarely or never consume alcohol or those with high intake (3-5 drinks/day) and binge drinkers (21). 
This finding may be attributable to the protective effects of low to moderate alcohol consumption on the risk of CAD. Castelnuvovo, et al studied 1 million subjects and almost 10,000 deaths in their meta-analysis of 34 prospective studies on alcohol and all cause mortality and observed a J-shaped relationship between alcohol and total mortality( Figure 2) (22).

In the prospective Physicians Health Study of 21,537 male physicians followed for over 12 years, Albert et al., observed that men who drank 2-6 drinks/week had a significantly reduced risk of SCD compared to those who rarely or never consumed alcohol(23). Unfortunately, this study lacks data on drink type or drinking pattern. In the British Regional Heart Study there was a two fold increase in SCD in individuals who consumed six or more drinks/day, a finding most evident in cases where there was no preexisting heart disease (Figure 3)(24). A study of middle aged Swedish men in Uppsala found that a larger proportion of SCD occurred in men known to have alcohol indulgence issues(25). In the Auckland Study, a higher proportion of heavy drinkers who sustained a myocardial infarction were likely to have that event manifest as $\operatorname{SCD}(26)$. In the Yugoslavia Cardiovascular Study, recent inebriation was positively correlated with $\operatorname{SCD}(27)$.

Greenspon et al., performed electrophysiologic studies on 14 patients with known heart disease and found that administration of alcohol precipitated sustained and nonsustained VT, as well as AFL and AF(28). This study albeit small was significant in that it touched on various mechanisms by which alcohol could potentially be an 
arrhythmogenic stimulus. Table II summarizes studies implicating alcohol as an etiologic factor for VT and SCD.

The majority of large studies reviewed above are in agreement that alcohol has a definite relationship to SCD. It appears also that there is a dose response effect as in the case of supraventricular arrhythmias discussed previously. Notably the Auckland Study, Wannamathee et al., and the US Male Physician Study report an increased incidence of SCD at higher levels of alcohol consumption.

Arrhythmias in chronic alcohol abusers may represent clinical manifestations of dilated cardiomyopathy. Therefore, evaluation of cardiac function is mandatory. This issue is crucial, mostly in relation to SCD which can occur in alcoholic cardiomyopathy patients. Over time, alcohol abuse alters calcium homeostasis, mitochondrial function and the structure and function of contractile proteins, resulting in impaired myocardial function (29). These cellular and sub cellular effects eventually translate into increased left ventricular dilatation and mass, thinning and left ventricular dysfunction (systolic and diastolic). It has also been noted that abstinence from alcohol in patients with alcoholic cardiomyopathy improved the risk of SCD, thought to be related to improved left ventricular function (30).

\section{Basic Investigations into Alcohol induced Arrhythmias}

In this section we will review the important aspects of the action of alcohol on the heart which are thought to be related to its arrythmogenic effects. 


\section{Effect of Alcohol on the QT interval}

Prolongation of the QT interval is associated with ventricular arrhythmias and SCD. Studies in alcoholics have demonstrated QT interval prolongation(31). In alcoholics with liver disease, QT prolongation was an independent prognostic factor for SCD (Figure 4 )(32). Alcoholics also tend to have a higher incidence of polysubstance abuse and psychiatric morbidity, often requiring QT-prolonging medications such as tricyclic-antidepressants, SSRI's and lithium, potentially providing a veritable "cocktail de la mort!"

Berger et al, developed the QT variability index (QTvi), calculated by normalizing the QT to heart rate variability as a non-invasive marker of cardiac repolarization lability(33). In a study of patients experiencing acute alcohol withdrawal, Bär et al., found the QTvi was increased in alcohol withdrawers compared to controls(34). Possible mechanisms of increased QTvi include increased sympathetic activity in the setting of alcohol withdrawal, concurrent hypokalemia and hypomagnesaemia altering transmembrane potentials, and direct myocardial damage from alcohol(4). Alcohol withdrawal is also associated with rebound $\beta$-adrenergic hypersensitivity and elevated catecholamine levels, both of which in the milieu of electrolyte disarray, stages a dangerous setting for ventricular and other arrhythmias(35).

\section{Alcohol and Heart Rate Variability and Baroreceptor Sensitivity}


Electrophysiological findings associated with alcohol withdrawal syndrome include decreased heart rate variability (HRV) and reduced baroreflex sensitivity, both of which correlate with cardiac events(34). In healthy subjects, acute alcohol intake causes a significant decrease in HRV due to diminished vagal modulation(36, 37). A similar effect was noted in patients with CAD and acute alcohol exposure (38).

Carretta et al, found that alcohol reduces baroreflex sensitivity in healthy and hypertensive subjects, even before the onset of changes in heart rate or blood pressure (39). Animal and normal human volunteer studies have confirmed similar acute, as well as chronic, effects of alcohol on baroreceptor responsiveness (40, 41).. Gender-related differences in baroreceptor reflex control mechanisms have been demonstrated which might explain different dose response relationships between alcohol and arrhythmias in males and females (42).

\section{Alcohol and Nutritional Abnormalities}

Electrolyte abnormalities frequently encountered in chronic alcoholics, acute alcohol intoxication and alcohol withdrawal include hypomagnesaemia and hypokalemia $(43,44)$. These electrolyte abnormalities may be due to a direct effect of alcohol, secondary to alcohol-induced diseases affecting other organs, malnutrition, vomiting or diarrhea, or as part of alcoholic ketoacidosis $(45,46)$. Hypokalemia, commonly seen in chronic alcoholics, can predispose to VT, torsades de pointes and $\mathrm{SCD}(47)$. 
At a subcellular level, magnesium is intricately linked to calcium (channel activity) and potassium (transport) in the myocyte, affecting cell membrane stability and impulse generation(48). Alcohol exacerbates magnesium deficiency, mainly through excessive urinary loss $(49,50)$. Alcoholics can be malnourished. Additionally, alcoholics can have endocrine abnormalities such as secondary aldosteronism (especially in cirrhotics). Animal studies have shown that during acute alcohol withdrawal, catecholamine-induced lipolysis releases fatty acids that can bind intracellular magnesium (51). Magnesium deficiency is associated with QT interval prolongation instigating malignant ventricular arrhythmias such as torsades de pointes (52-54). Finally, magnesium deficiency is closely tied to potassium deficiency and can result in refractory hypokalemia $(55,56)$ Interestingly, dietary magnesium supplementation in a rat model attenuates alcoholinduced myocardial dysfunction(57).

\section{Animal Models Relating to Alcohol Induced Arrhythmias}

Studies on isolated rat atria have demonstrated that alcohol causes shortening of the action potential and decreases contractility, which could predispose to ectopic complexes and arrhythmias (58). Rat cardiomyocytes exposed to alcohol have a dose dependant depression in contractility due, at least in part, to a depletion of sarcoplasmic calcium(59). Studies in mice and human tissue have shown that alcohol causes direct myocardial ultrastructural damage, including edema of sarcoplasmic reticulum, fragmentation of contractile elements, expansion of intercalated disc, and fatty deposits 
$(60,61)$. Anadon et al., demonstrated in a porcine model that acute alcohol infusion resulted in dose dependant atrial arrhythmias, including $\operatorname{AFL}(62)$.

\section{Conclusion}

We conclude there is credible evidence in the literature for a strong association between alcohol and arrhythmias. This is especially true for supraventricular arrhythmias; predominantly AF in younger men who tend to drink more. Alcohol is also positively correlated with VT and SCD in heavier drinkers. Chronic alcohol abuse produces multiple physiologic aberrancies in the heart, including ultrastructural changes, effects on the QT interval and HRV, and proarrhythmic electrolyte abnormalities. This creates a substrate for triggering nonfatal and fatal arrhythmias. (Figure 5) Indeed a significant number of alcoholics, especially those with coexistent ischemic heart disease, are victims of $\operatorname{SCD}(24,63)$.

Moderate regular alcohol consumption produces desirable health benefits which are lost as the dose escalates or a binge pattern is assumed. The relation of alcohol to arrhythmias has strong evidence in the literature based on epidemiological studies, basic science investigations and animal models, as we have outlined. However, the exact relationship between alcohol and arrhythmias continues to be controversial and potentially can never be answered as there is little likelihood of a randomized controlled trial addressing these issues. Nevertheless, the ACC/AHA guidelines do suggest complete 
abstinence from alcohol when a correlation is suspected between alcohol use and ventricular arrhythmias. 


\section{References:}

1. O'Brien R, Chafetz ME. The encyclopedia of alcoholism. New York, N.Y.: Facts on File; 1982.

2. Kloner RA, Rezkalla SH. To Drink or Not to Drink? That Is the Question. Circulation 2007; 116(11):1306-1317.

3. Mackenzie J. The study of the pulse, arterial, venous, and hepatic, and of the movements of the heart. Edinburgh and London: Y.J. Pentland; 1902.

4. Kuppari M KM. Alcohol and Cardiovascular Disease: John Wiley \& Sons Inc; 2007.

5. Aalsmeer W, Wenckebach, KF.: Monograph, Urban and Schwarzenberg. The heart and circulatory system in beri-beri. American Heart Journal 1929; 4(5):630-631.

6. Keefer CS. The Beriberi Heart. Arch Intern Med 1930; 45(1):1-22.

7. Evans W. The electrocardiogram of alcoholic cardiomyopathy. British heart journal 1959; 21:445-456.

8. Brigden W, Robinson J. Alcoholic Heart Disease. British medical journal 1964; 2(5420):1283-1289.

9. Ettinger PO, Wu CF, De La Cruz C, Jr., Weisse AB, Ahmed SS, Regan TJ. Arrhythmias and the "Holiday Heart": alcohol-associated cardiac rhythm disorders. American heart journal 1978; 95(5):555-562.

10. Lamb LE, Pollard LW. Atrial Fibrillation in flying personnel. Circulation 1964; 29:694-701.

11. Koskinen P, Kupari M, Leinonen H, LuomanmuÂ'aki K. Alcohol and new onset atrial fibrillation: a case-control study of a current series. British heart journal 1987; 57(5):468-473.

12. Koskinen P, Kupari M, Leinonen H. Role of alcohol in recurrences of atrial fibrillation in persons less than 65 years of age. The American journal of cardiology 1990; 66(12):954-958.

13. Djoussé L, Levy D, Benjamin EJ, Blease SJ, Russ A, Larson MG, Massaro JM, D'Agostino RB, Wolf PA, Ellison RC. Long-term alcohol consumption and the risk of atrial fibrillation in the Framingham Study. The American journal of cardiology 2004; 93(6):710-713.

14. Frost L, Vestergaard P. Alcohol and Risk of Atrial Fibrillation or Flutter: A Cohort Study. Archives of Internal Medicine 2004; 164(18):1993-1998.

15. Mukamal KJ, Tolstrup JS, Friberg J, Jensen G, GruÂ'nbaek M. Alcohol consumption and risk of atrial fibrillation in men and women: the Copenhagen City Heart Study. Circulation 2005; 112(12):1736-1742.

16. Conen D, Tedrow UB, Cook NR, Moorthy MV, Buring JE, Albert CM. Alcohol Consumption and Risk of Incident Atrial Fibrillation in Women. JAMA 2008; 300(21):2489-2496.

17. Marcus GM, Smith LM, Whiteman D, Tseng ZH, Badhwar N, Lee BK, Lee RJ, Scheinman MM, Olgin JE. Alcohol intake is significantly associated with atrial flutter in patients under 60 years of age and a shorter right atrial effective refractory period. Pacing and clinical electrophysiology : PACE 2008; 31(3):266-272.

18. Cohen EJ, Klatsky AL, Armstrong MA. Alcohol use and supraventricular arrhythmia. The American journal of cardiology 1988; 62(13):971-973. 
19. Koskinen P, Kupari M. Alcohol consumption of patients with supraventricular tachyarrhythmias other than atrial fibrillation Alcohol Alcohol 1991; 26(2):199-206.

20. Psaty BM, Manolio TA, Kuller LH, Kronmal RA, Cushman M, Fried LP, White R, Furberg CD, Rautaharju PM. Incidence of and Risk Factors for Atrial Fibrillation in Older Adults. Circulation 1997; 96(7):2455-2461.

21. Zipes DP, Camm AJ, Borggrefe M, Buxton AE, Chaitman B, Fromer M, Gregoratos G, Klein G, Moss AJ, Myerburg RJ, Priori SG, Quinones MA, Roden DM, Silka MJ, Tracy C, Smith SC, Jr., Jacobs AK, Adams CD, Antman EM, Anderson JL, Hunt SA, Halperin JL, Nishimura R, Ornato JP, Page RL, Riegel B, Priori SG, Blanc J-J, Budaj A, Camm AJ, Dean V, Deckers JW, Despres C, Dickstein K, Lekakis J, McGregor K, Metra M, Morais J, Osterspey A, Tamargo JL, Zamorano JL. ACC/AHA/ESC 2006 Guidelines for Management of Patients With Ventricular Arrhythmias and the Prevention of Sudden Cardiac Death: A Report of the American College of Cardiology/American Heart Association Task Force and the European Society of Cardiology Committee for Practice Guidelines (Writing Committee to Develop Guidelines for Management of Patients With Ventricular Arrhythmias and the Prevention of Sudden Cardiac Death). $J$ Am Coll Cardiol 2006; 48(5):e247-346.

22. Di Castelnuovo A, Costanzo S, Bagnardi V, Donati MB, Iacoviello L, de Gaetano G. Alcohol Dosing and Total Mortality in Men and Women: An Updated Meta-analysis of 34 Prospective Studies. Arch Intern Med 2006; 166(22):2437-2445.

23. Albert CM, Manson JE, Cook NR, Ajani UA, Gaziano JM, Hennekens CH. Moderate Alcohol Consumption and the Risk of Sudden Cardiac Death Among US Male Physicians. Circulation 1999; 100(9):944-950.

24. Wannamethee G, Shaper AG. Alcohol and sudden cardiac death. British heart journal 1992; 68(5):443-448.

25. Lithell H, Aberg H, Selinus I, Hedstrand H. Alcohol intemperance and sudden death. British medical journal (Clinical research ed) 1987; 294(6585):1456-1458.

26. Fraser GE, Upsdell M. Alcohol and other discriminants between cases of sudden death and myocardial infarction. Am J Epidemiol 1981; 114(4):462-476.

27. Kozarevic D, Demirovic J, Gordon T, Kaelber CT, McGee D, Zukel WJ. Drinking habits and coronary heart disease: the Yugoslavia cardiovascular disease study. Am J Epidemiol 1982; 116(5):748-758.

28. Greenspon AJ, Schaal SF. The "holiday heart": electrophysiologic studies of alcohol effects in alcoholics. Annals of internal medicine 1983; 98(2):135-139.

29. Piano MR. Reviews - Alcoholic Cardiomyopathy: Incidence, Clinical Characteristics, and Pathophysiology. Chest : official publication of the American College of Chest Physicians 2002; 121(5):1638.

30. Fauchier L. Communications to the editor - Alcoholic Cardiomyopathy and Ventricular Arrhythmias. Chest : official publication of the American College of Chest Physicians 2003; 123(4):1320.

31. Kino M, Imamitchi H, Morigutchi M, Kawamura K, Takatsu T. Cardiovascular status in asymptomatic alcoholics, with reference to the level of ethanol consumption. British heart journal 1981; 46(5):545-551.

32. Day CP, James OF, Butler TJ, Campbell RW. QT prolongation and sudden cardiac death in patients with alcoholic liver disease. Lancet 1993; 341(8858):1423-1428. 
33. Berger RD, Kasper EK, Baughman KL, Marban E, Calkins H, Tomaselli GF. Beat-to-Beat QT Interval Variability : Novel Evidence for Repolarization Lability in Ischemic and Nonischemic Dilated Cardiomyopathy. Circulation 1997; 96(5):1557-1565. 34. Bär KJ, Boettger MK, Koschke M, Boettger S, GroteluÂ'uschen M, Voss A, Yeragani VK. Increased QT interval variability index in acute alcohol withdrawal. Drug and alcohol dependence 2007; 89(2-3):2-3.

35. Kähkönen S. Responses to cardiovascular drugs during alcohol withdrawal Alcohol Alcohol 2006; 41(1):11-13.

36. Koskinen P, Virolainen J, Kupari M. Acute alcohol intake decreases short-term heart rate variability in healthy subjects. Clinical science (London, England : 1979) 1994; 87(2):225-230.

37. Weise F, Krell D, Brinkhoff N. Acute alcohol ingestion reduces heart rate variability. Drug and Alcohol Dependence 1986; 17(1):89-91.

38. Rossinen J, Viitasalo M, Partanen J, Koskinen P, Kupari M, Nieminen MS. Effects of Acute Alcohol Ingestion on Heart Rate Variability in Patients With Documented Coronary Artery Disease and Stable Angina Pectoris. The American Journal of Cardiology 1997; 79(4):487-491.

39. Carretta R, Fabris B, Bardelli M, Muiesan S, Fischetti F, Cesanelli R, Pizzolitto A, Bianchetti A, Campanacci L. Acute effects of intravenous infusions of alcohol on baroreceptor sensitivity in essential hypertension. Cardiovasc Res 1988; 22(3):226-230. 40. Abdel-Rahman AR, Merrill RH, Wooles WR. Effect of acute ethanol administration on the baroreceptor reflex control of heart rate in normotensive human volunteers. Clinical science (London, England : 1979) 1987; 72(1):113-122. 41. Abdel-Rahman AR, Dar MS, Wooles WR. Effect of chronic ethanol administration on arterial baroreceptor function and pressor and depressor responsiveness in rats. J Pharmacol Exp Ther 1985; 232(1):194-201.

42. Abdel-Rahman AR, Merrill RH, Wooles WR. Gender-related differences in the baroreceptor reflex control of heart rate in normotensive humans. J Appl Physiol 1994; 77(2):606-613.

43. Meyer JG, Urban K. Electrolyte changes and acid base balance after alcohol withdrawal, with special reference to rum fits and magnesium depletion. Journal of neurology 1977; 215(2):135-140.

44. Stasiukyniene V. Blood plasma potassium, sodium and magnesium levels in chronic alcoholism during alcohol withdrawal. Medicina (Kaunas) 2002; 38(9):892-895.

45. Ragland G. Electrolyte abnormalities in the alcoholic patient. Emergency medicine clinics of North America 1990; 8(4):761-773.

46. Wrenn KD, Slovis CM, Minion GE, Rutkowski R. The syndrome of alcoholic ketoacidosis. The American journal of medicine 1991; 91(2):119-128.

47. Alfonzo AVM, Isles C, Geddes C, Deighan C. Potassium disorders--clinical spectrum and emergency management. Resuscitation 2006; 70(1):10-25.

48. Reinhart RA. Clinical correlates of the molecular and cellular actions of magnesium on the cardiovascular system. American Heart Journal 1991; 121(5):15131521.

49. Kalbfleisch JM, Lindeman RD, Ginn HE, Smith WO. Effects of ethanol administration on urinary excretion of magnesium and other electrolytes in alcoholic and normal subjects. The Journal of clinical investigation 1963; 42:1471-1475. 
50. Seelig M. Cardiovascular consequences of magnesium deficiency and loss: pathogenesis, prevalence and manifestations--magnesium and chloride loss in refractory potassium repletion. The American journal of cardiology 1989; 63(14).

51. Flink EB, Shane SR, Scobbo RR, Blehschmidt NG, McDowell P. Relationship of free fatty acids and magnesium in ethanol withdrawal in dogs. Metabolism 1979; 28(8):858-865.

52. Al-Khatib SM, LaPointe NMA, Kramer JM, Califf RM. What Clinicians Should Know About the QT Interval. JAMA 2003; 289(16):2120-2127.

53. Ramee SR, White CJ, Svinarich JT, Warson TD, Fox RF. Torsade de pointes and magnesium deficiency. American Heart Journal 1985; 109(1):164-167.

54. Gonzalez MMC, Cavalcanti TC, Vianna CB, Timerman S. Hypomagnesaemia causing QT interval prolongation and torsade de pointes in an alcoholic patient. Resuscitation 2006; 70(3):346-347.

55. Whang R, Whang DD, Ryan MP. Refractory potassium repletion. A consequence of magnesium deficiency. Archives of internal medicine 1992; 152(1):40-45.

56. Rude RK. Physiology of magnesium metabolism and the important role of magnesium in potassium deficiency. The American Journal of Cardiology 1989; 63(14):G31-G34.

57. Ricardo A. Brown MC, Melissa Natavio, Pauline Petrovski, Jun Ren. Dietary Magnesium Supplementation Attenuates Ethanol-Induced Myocardial Dysfunction. Alcoholism: Clinical and Experimental Research 1998; 22(9):2062-2072.

58. Gimeno AL, Gimeno MF, Webb JL. Effects of ethanol on cellular membrane potentials and contractility of isolated rat atrium. The American journal of physiology 1962; 203:194-196.

59. Danziger RS, Sakai M, Capogrossi MC, Spurgeon HA, Hansford RG, Lakatta EG. Ethanol acutely and reversibly suppresses excitation-contraction coupling in cardiac myocytes. Circ Res 1991; 68(6):1660-1668.

60. Burch GE, Colcolough HL, Harb JM, Tsui CY. The effect of ingestion of ethyl alcohol, wine and beer on the myocardium of mice. The American journal of cardiology 1971; 27(5):522-528.

61. Hibbs RG, Ferrans VJ, Black WC, Weilbaecher DG, Walsh JJ, Burch GE. Alcoholic cardiomyopathy. An electron microscopic study. American Heart Journal 1965; 69(6):766-779.

62. María J. Anadon JA, Pablo González, Matilde Zaballos, Juan L. Delcan, Javier L. Guevara. Alcohol Concentration Determines the Type of Atrial Arrhythmia Induced in a Porcine Model of Acute Alcoholic Intoxication. Pacing and Clinical Electrophysiology 1996; 19(11):1962-1967.

63. Chenet L, McKee M, Leon D, Shkolnikov V, Vassin S. Alcohol and cardiovascular mortality in Moscow; new evidence of a causal association. $J$ Epidemiol Community Health 1998; 52(12):772-774. 


\section{Figures}

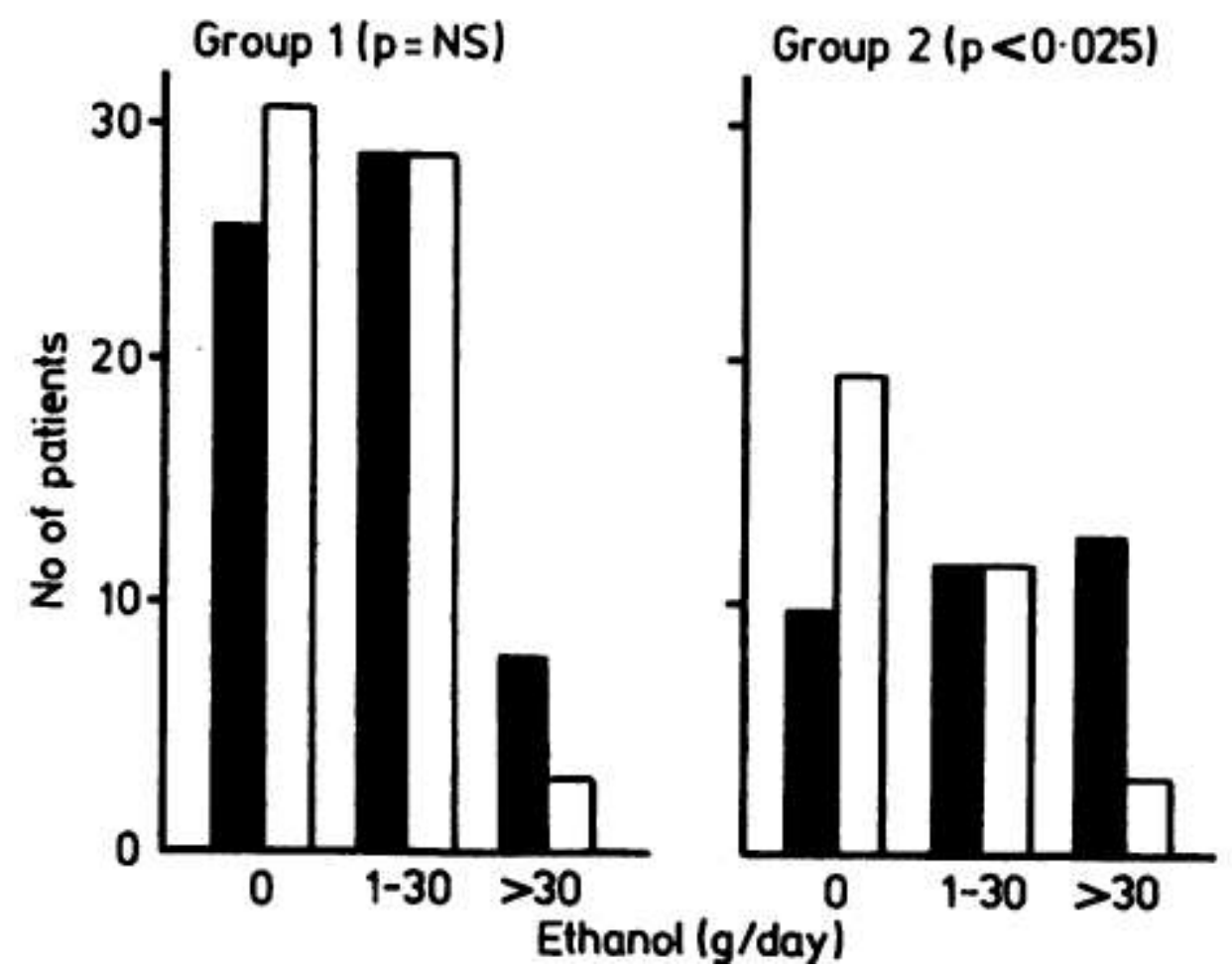

Figure 1. Average daily alcohol consumption of the patients (black columns) and their controls (white columns) during the week preceding atrial fibrillation Group 1, atrial fibrillation with an associated disease. Group 2, idiopathic atrial fibrillation. Reprinted with permission from Koskinen P, Kupari M, Leinonen H, LuomanmuÂ'aki K. Alcohol and new onset atrial fibrillation: a case-control study of a current series. British Heart Journal 1987;57(5):468-73. 


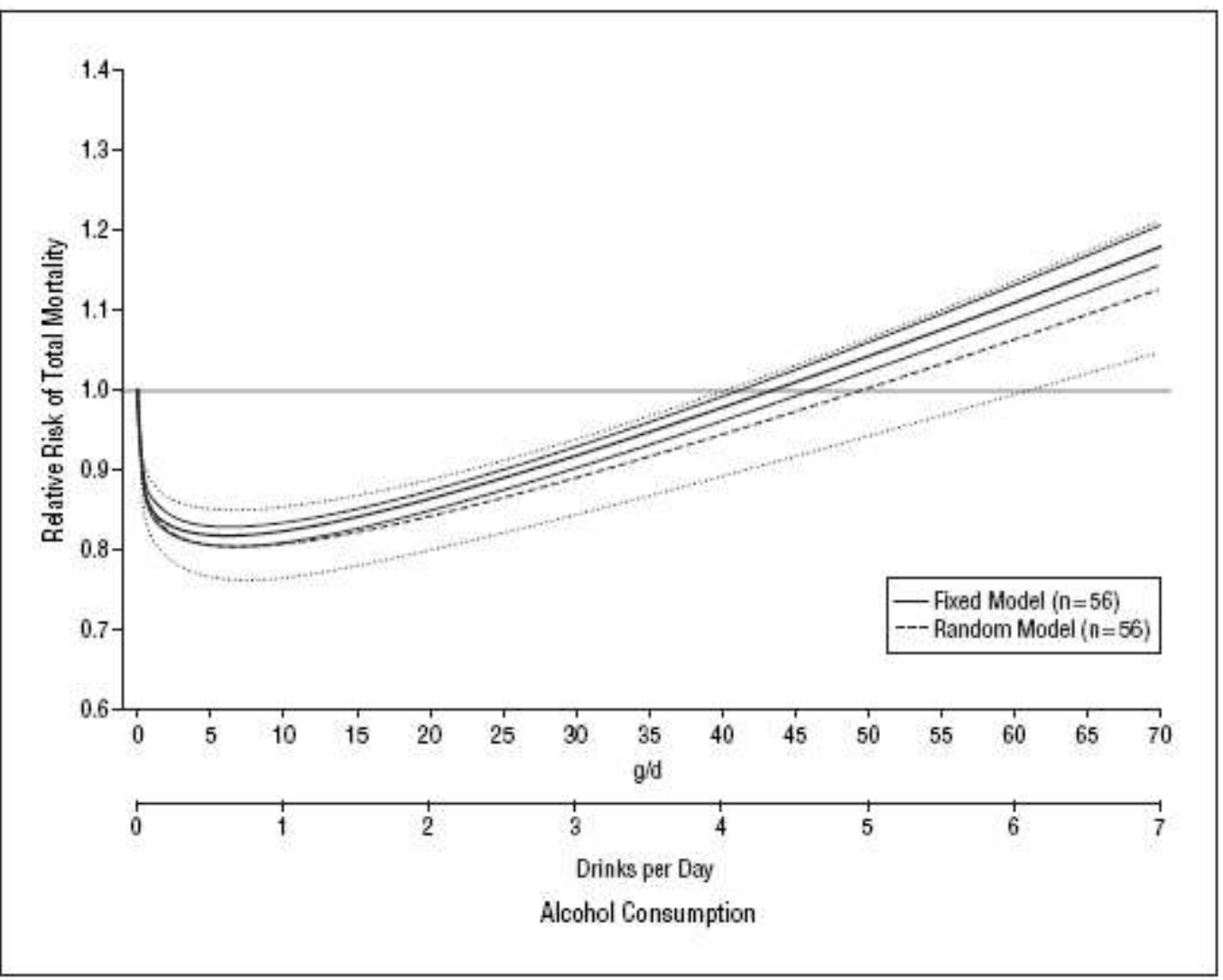

Figure 2: Relative risk of total mortality (95\% confidence interval) and alcohol intake extracted from 56 curves using fixed- and random-effects models. (Reprinted with permission. Di Castelnuovo A, Costanzo S, Bagnardi V, Donati MB, Iacoviello L, de Gaetano G. Alcohol Dosing and Total Mortality in Men and Women: An Updated Metaanalysis of 34 Prospective Studies. Arch Intern Med 2006;166(22):2437-2445. 


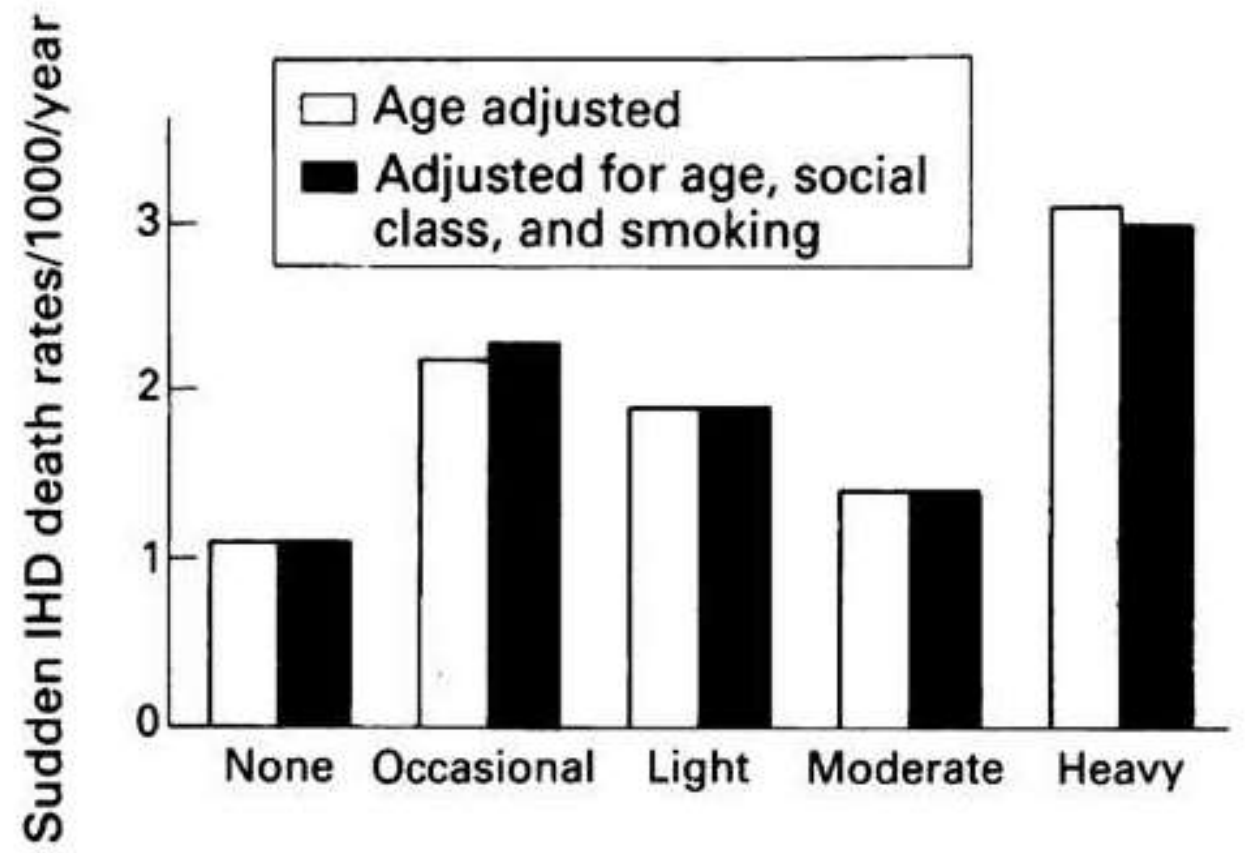

Figure 3: Abscissa refers to alcohol intake (adjusted for age and age, social class and smoking-none, occasional, light, moderate and heavy). Ordinate refers to sudden death rates/1000/year. IHD = ischemic heart disease. Reprinted with permission from Wannamethee G, Shaper AG. Alcohol and sudden cardiac death. British Heart Journal. $1992 ; 68(5): 443-8$. 


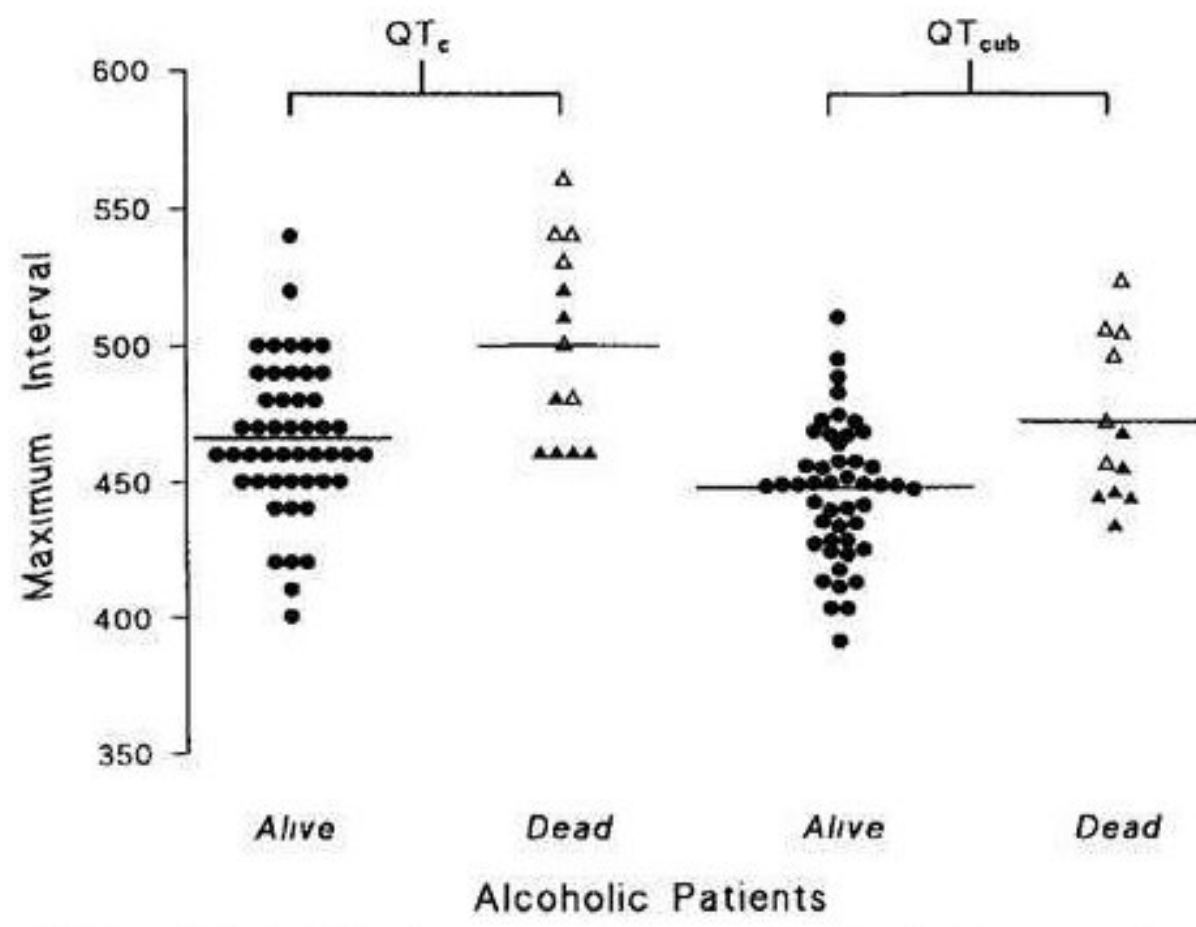

Figure 4: Corrected QT intervals in alcoholic patients and survival. $\Delta=$ cardiac sudden death, $\boldsymbol{\Delta}=$ non-cardiac cause of death. Horizontal lines represent means. QTc $=$ QT interval corrected for rate (Bazett's formula); QTcub $=$ QT interval corrected for rate (cube root formulae). Reprinted with permission from Day CP, James OF, Butler TJ, Campbell RW. QT prolongation and sudden cardiac death in patients with alcoholic liver disease. Lancet. 1993;341(8858):1423-8. 


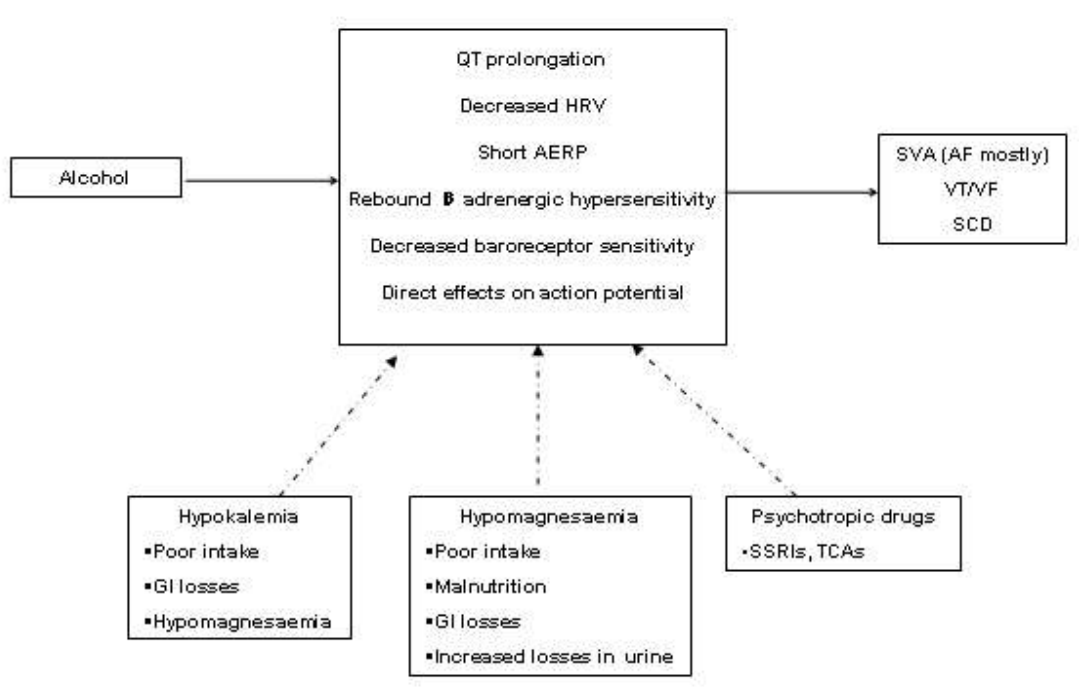

Figure 5: Potential mediators of alcohol-induced cardiac arrhythmias. TCA = tricyclic antidepressants, SSRI = selective serotonin reuptake inhibitors. 


\section{Tables}

Table 1: Studies of Alcohol and Supraventricular Arrhythmias

\begin{tabular}{|c|c|c|c|c|c|c|c|}
\hline Study & Study type & $\mathrm{N}$ & $\begin{array}{l}\text { Mean } \\
\text { age } \\
\text { (years) }\end{array}$ & $\begin{array}{l}\text { Alcohol } \\
\text { amount/pattern }\end{array}$ & Arrhythmia & Results & Comments \\
\hline $\begin{array}{l}\text { Lamb \& } \\
\text { Pollard } \\
1964^{12}\end{array}$ & Case series & 60 & 36.6 & Excessive & $\mathrm{AF}$ & $\begin{array}{l}\text { AF } \\
\text { occurred } \\
\text { when } \\
\text { arising } \\
\text { from } \\
\text { excess } \\
\text { use. }\end{array}$ & $\begin{array}{l}\text { Flying } \\
\text { personnel, } \\
\text { no control } \\
\text { group, } \\
\text { small sample } \\
\text { size. }\end{array}$ \\
\hline $\begin{array}{l}\text { Ettinger et } \\
\text { al } 1978^{11}\end{array}$ & Case series & 24 & 43 & $\begin{array}{l}\text { 6-10 } \\
\text { drinks/day }\end{array}$ & $\begin{array}{l}\text { AF, AFL, PAT, } \\
\text { VT }\end{array}$ & $\begin{array}{l}\text { Episodes } \\
\text { followed } \\
\text { heavy } \\
\text { weekend } \\
\text { or } \\
\text { holiday } \\
\text { sprees. }\end{array}$ & $\begin{array}{l}\text { "Holiday } \\
\text { Heart", } \\
\text { no control } \\
\text { group, } \\
\text { small sample } \\
\text { size }\end{array}$ \\
\hline $\begin{array}{l}\text { Koskinen \& } \\
\text { Kupari } \\
1987^{13}\end{array}$ & $\begin{array}{l}\text { Case- } \\
\text { control }\end{array}$ & 100 & 48 & $\begin{array}{l}1-30 />30 \\
\text { g/day }\end{array}$ & $\mathrm{AF}$ & $\begin{array}{l}15-30 \% \\
\text { of } \mathrm{AF} \\
\text { may be } \\
\text { alcohol } \\
\text { related. }\end{array}$ & $\begin{array}{l}\text { Small } \\
\text { sample size, } \\
\text { short follow } \\
\text { up. }\end{array}$ \\
\hline $\begin{array}{l}\text { Kaiser } \\
\text { Permanente } \\
\text { study } \\
\text { Cohen et al } \\
1988^{20}\end{array}$ & $\begin{array}{l}\text { Prospective } \\
\text { cohort }\end{array}$ & 10,7139 & -- & 6+drinks/day & AF,AFL,APC,SVT & $\begin{array}{l}\text { Relative } \\
\text { risk }=2.3 \\
\text { for } \\
6+\mathrm{vs}<1 \\
\text { drink }\end{array}$ & $\begin{array}{l}\text { Large cohort, } \\
\text { role of } \\
\text { bingeing not } \\
\text { studied }\end{array}$ \\
\hline $\begin{array}{l}\text { Framingham } \\
\text { Study } \\
\text { Djoussé et } \\
\text { al } 2004^{15}\end{array}$ & $\begin{array}{l}\text { Case- } \\
\text { control }\end{array}$ & 10,333 & $\begin{array}{l}44.60^{\Uparrow} \\
47 q\end{array}$ & $>36$ g/day & $\mathrm{AF}$ & $\begin{array}{l}34 \% \\
\text { increase } \\
\text { in AF }\end{array}$ & $\begin{array}{l}\text { Large } \\
\text { sample size, } \\
\text { long follow } \\
\text { up, } \\
\text { adjusted for } \\
\text { confounders. }\end{array}$ \\
\hline $\begin{array}{l}\text { Danish Diet, } \\
\text { Cancer \& } \\
\text { Health } \\
\text { Study } \\
\text { Frost et al } \\
2004^{16}\end{array}$ & $\begin{array}{l}\text { Prospective } \\
\text { cohort }\end{array}$ & 47,949 & 56 & $\begin{array}{l}>20 \mathrm{~g} / \text { day in }{ }^{\lambda} \\
\operatorname{not} \phi\end{array}$ & $\mathrm{AF}, \mathrm{AFL}$ & $\begin{array}{l}25-46 \% \\
\text { increase } \\
\text { in } \hat{\sigma}\end{array}$ & $\begin{array}{l}\text { Large cohort } \\
\text { study, } \\
\text { adjusted for } \\
\text { confounders. } \\
\text { limited } \\
\text { power in } \bigcirc\end{array}$ \\
\hline $\begin{array}{l}\text { Copenhagen } \\
\text { City Heart } \\
\text { Study } \\
\text { Mukamel et }\end{array}$ & $\begin{array}{l}\text { Prospective } \\
\text { cohort }\end{array}$ & 16,415 & 50 & $\begin{array}{l}>35 \text { drinks/wk } \\
\text { in } \delta\end{array}$ & $\mathrm{AF}$ & $\begin{array}{l}\text { Relative } \\
\text { risk=1.45 }\end{array}$ & $\begin{array}{l}\text { Large } \\
\text { observational } \\
\text { study, Native } \\
\text { born Danes }\end{array}$ \\
\hline
\end{tabular}




\begin{tabular}{|c|c|c|c|c|c|c|c|}
\hline al $2005^{17}$ & & & & & & & \\
\hline $\begin{array}{l}\text { Women's } \\
\text { Health } \\
\text { Study } \\
\text { Conen et al } \\
2008^{18}\end{array}$ & $\begin{array}{l}\text { Prospective } \\
\text { cohort }\end{array}$ & 34,715 & 53 & $\begin{array}{l}>2 \text { drinks/day } \\
\text { in } q\end{array}$ & $\mathrm{AF}$ & $\begin{array}{l}1.6 \text { fold } \\
\text { risk } \\
\text { compared } \\
\text { to non- } \\
\text { drinkers }\end{array}$ & $\begin{array}{l}\text { Large cohort } \\
\text { study, } \\
\text { long follow } \\
\text { up }\end{array}$ \\
\hline
\end{tabular}

(AF-Atrial Fibrillation; AFL-Atrial Flutter; APC-Atrial Premature Contraction; PAT-Paroxysmal

Atrial Tachycardia; SVT-Supra Ventricular Tachycardia; VT-Ventricular Tachycardia)

Table II: Studies of Alcohol and VT/SCD

\begin{tabular}{|c|c|c|c|c|c|c|c|}
\hline Study & Study type & $\mathrm{N}$ & $\begin{array}{l}\text { Mean } \\
\text { age } \\
\text { (years) } \\
\end{array}$ & Alcohol/Habits & Arrhythmia & Results & Comments \\
\hline $\begin{array}{l}\text { Auckland } \\
\text { study } \\
\text { Fraser et al, } \\
1981^{27}\end{array}$ & $\begin{array}{l}\text { Registry } \\
\text { based } \\
\text { cohort }\end{array}$ & 326 & 58.6 & $\begin{array}{l}167 \mathrm{~g} / \text { week, } \\
\text { o } 194 \mathrm{~g} / \text { week, } \\
\text { o } 75 \mathrm{~g} / \text { week, }\end{array}$ & SCD & $\begin{array}{l}\text { High alcohol } \\
\text { intake is } \\
\text { seen } \\
\text { frequently in } \\
\text { acute } \\
\text { coronary } \\
\text { syndromes } \\
\text { manifest as } \\
\text { SCD }\end{array}$ & $\begin{array}{l}\text { Did not prove } \\
\text { alcohol is } \\
\text { associated with } \\
\text { VF. }\end{array}$ \\
\hline $\begin{array}{l}\text { Yugoslavia } \\
\text { Cardiovascular } \\
\text { Study } \\
\text { Kozarevic et al } \\
1982^{28}\end{array}$ & $\begin{array}{l}\text { Cohort } \\
\text { study }\end{array}$ & 11,121 & 46 & $\begin{array}{l}\text { Alcohol } \\
\text { summary } \\
\text { codes }(0-16)\end{array}$ & SCD & $\begin{array}{l}\text { Recent } \\
\text { drunkenness } \\
\text { associated } \\
\text { with sudden } \\
\text { death. }\end{array}$ & $\begin{array}{l}\text { Only Yugoslav } \\
\text { males studied }\end{array}$ \\
\hline $\begin{array}{l}\text { Holiday Heart } \\
\text { Greenspon et } \\
\text { al } 1983^{29}\end{array}$ & Case series & 14 & 57 & EP study & $\begin{array}{l}\text { VT, } \\
\text { NSVT, } \\
\text { VPC }\end{array}$ & $\begin{array}{l}\text { Increased } \\
\text { risk in } \\
\text { patients with } \\
\text { heart disease }\end{array}$ & $\begin{array}{l}\text { Induction of } \\
\text { tachyarrhythmia } \\
\text { with small } \\
\text { doses of alcohol } \\
\text { in EP lab }\end{array}$ \\
\hline $\begin{array}{l}\text { Lithell et al } \\
1987^{26}\end{array}$ & $\begin{array}{l}\text { Case- } \\
\text { control }\end{array}$ & 2700 & 50 & $\begin{array}{l}\text { Registration at } \\
\text { Temperance } \\
\text { Board }\end{array}$ & SCD & $\begin{array}{l}\text { Large } \\
\text { proportion of } \\
\text { SCD in } \\
\text { individuals } \\
\text { with known } \\
\text { alcohol } \\
\text { intemperance }\end{array}$ & $\begin{array}{l}\text { SCD more } \\
\text { common in } \\
\text { alcoholics who } \\
\text { have MI }\end{array}$ \\
\hline $\begin{array}{l}\text { Wannamethee } \\
\text { et al } 1992^{25}\end{array}$ & $\begin{array}{l}\text { Prospective } \\
\text { cohort }\end{array}$ & 7,735 & 50 & $>6$ drinks/day & SCD & $\begin{array}{l}\text { Two fold } \\
\text { increase in } \\
\text { SCD risk }\end{array}$ & $\begin{array}{l}\text { Study accounts } \\
\text { for pre-existing } \\
\text { heart disease }\end{array}$ \\
\hline $\begin{array}{l}\text { US Male } \\
\text { Physicians \& } \\
\text { SCD } \\
\text { Albert et al } \\
1999^{24}\end{array}$ & $\begin{array}{l}\text { Prospective } \\
\text { cohort }\end{array}$ & 21,537 & 53 & $\begin{array}{l}2-6 \\
\text { drinks/week }\end{array}$ & SCD & $\begin{array}{l}\text { Decreased } \\
\text { SCD risk }\end{array}$ & $\begin{array}{l}\text { No information } \\
\text { on drink type or } \\
\text { drinking pattern }\end{array}$ \\
\hline
\end{tabular}


(MI-Myocardial Infarction; NSVT-Non-Sustained Ventricular Tachycardia; SCD-Sudden Cardiac Death; VF-Ventricular Fibrillation; VPC-Ventricular Premature Complex) 